\title{
Enfermedades genitourinarias en el antiguo Perú
}

\author{
Genitourinary diseases in ancient Peru
}

Emiliano Paico-Vílchez ${ }^{1}$ y Emiliano Paico-Zumaeta ${ }^{2}$

\begin{abstract}
Resumen
Los autores presentan las enfermedades genitourinarias que sufrieron los aborígenes peruanos y los métodos que emplearon para curarlas. Se recurre a las representaciones en los ceramios de las culturas Mochica y Virú, y en la información brindada por los cronistas.
\end{abstract}

Palabras claves: enfermedad, genitourinarias, ceramios, Mochica, Virú, cronistas, Inca.

\begin{abstract}
The authors present the genitourinary diseases suffered by the Peruvian aborigines and the methods they used to cure them. It is resorted to the representations in the ceramiums of the Mochica and Viru cultures, and in the information provided by the chroniclers.
\end{abstract}

Keywords: disease, genitourinary, ceramics, Mochica, Viru, chroniclers, Inca.

Escrudiñando escrupulosamente los escritos de los historiadores o cronistas de la conquista y analizando los ceramios de antiguas culturas peruanas encontramos información de que los aborígenes del antiguo Perú adolecieron de enfermedades genitourinarias, aunque éstas, al parecer, no fueron tan frecuentes como otras enfermedades.

Tanto los cronistas peninsulares como los de sangre india informan de la existencia de las enfermedades

Cirujano pediátrico. Profesor de la Facultad de Medicina de la Universidad Privada Antenor Orrego y ex jefe del Servicio de Cirugía Pediátrica y del Servicio de Especialidades Médicas del Hospital Belén de Trujillo, Perú.

2 Estudiante de la Facultad de Ciencias de la Comunicación de la Universidad Privada Antenor Orrego, Trujillo, Perú. del tracto urinario, especialmente nos relatan la forma cómo curaban dichos males. Sin embargo, no mencionan las enfermedades de los genitales, excepto de la sífilis y el hermafroditismo.

La cerámica por su parte, suministra información de las enfermedades de los genitales, más no de las del tracto urinario. Se sabe muy bien que los ceramistas solo plasmaban en sus obras lo que ellos observaban; entonces, es lógico pensar que no retrataban personas con enfermedades internas como la del riñón, uréteres, vejiga y uretra.

El propósito del presente artículo no es más que informar las enfermedades genitourinarias que sufrieron los aborígenes del antiguo Perú y los métodos utilizados para curar estas dolencias.

Los cronistas de la conquista que se han ocupado de las enfermedades genitourinarias en el antiguo Perú manifiestan que estos males no eran frecuentes entre los aborígenes.

La gran mayoría de los cronistas consideran que la inmunidad o poca frecuencia de las enfermedades del sistema urinario se debía al hábito de beber sustancias diuréticas como la chicha de maíz; en cambio, el padre Antonio de la Calancha, cronista español, asevera que se debía a la complexión fisiológica de los indígenas y no a la chicha: "Que 
como la beben algunos negros o españoles y no les conocen estos privilegios, se debe atribuir a la complexión y no a la bebida". ${ }^{1}$

El maíz era muy empleado por los aborígenes peruanos, no solamente en sus alimentos y en sus ceremonias o ritos religiosos sino también, según algunos cronistas, para tratar las enfermedades del tracto urinario.

Al respecto el cronista Garcilaso de la Vega refiere lo siguiente: "han hallado que el maiz, además de ser mantenimiento de tanta sustancia, es de mucho provecho para el mal de riñones, dolor de ijada, pasión de piedras, retención de orina, dolor de la vejiga y del caño, ...casi ninguno se halla que tenga dichas pasiones; lo cual atribuyeron a la común bebida de ellos (la chicha) que es el brebaje del maiz". ${ }^{2}$

Por su parte, el padre Acosta refiere que la chicha preparada de harina de maíz tostado "la usaban los indios más pulidos por medicina, porque en efecto hallan que para los riñones y la orina es muy saludable bebido por donde se halla en indios semejante mal." 3

Para tratar la infección de los riñones y vejiga, según el cronista español padre Bernabé Cobo, empleaban el cocimiento de las hojas de oca y el de achuma, que "quitan el incendio y ardor demasiado de orina". ${ }^{4}$ Este cronista también menciona al cocimiento de las hojas de la muña que "limpia las llagas y materias de los riñones y vejiga" y al cocimiento de pinco pinco que "contiene a la sangre que sale por la orina".

Para la fiebre, síntoma común a muchas enfermedades, empleaban vegetales que tenían efectos antipiréticos. Garcilaso de la Vega nombra a la infusión de paico que, entre otras propiedades, combate la fiebre; hecho que fue comprobado en el inca Atahualpa que enfermó con fiebre alta cuando estaba preso en Cajamarca. ${ }^{2}$ El padre Cobo

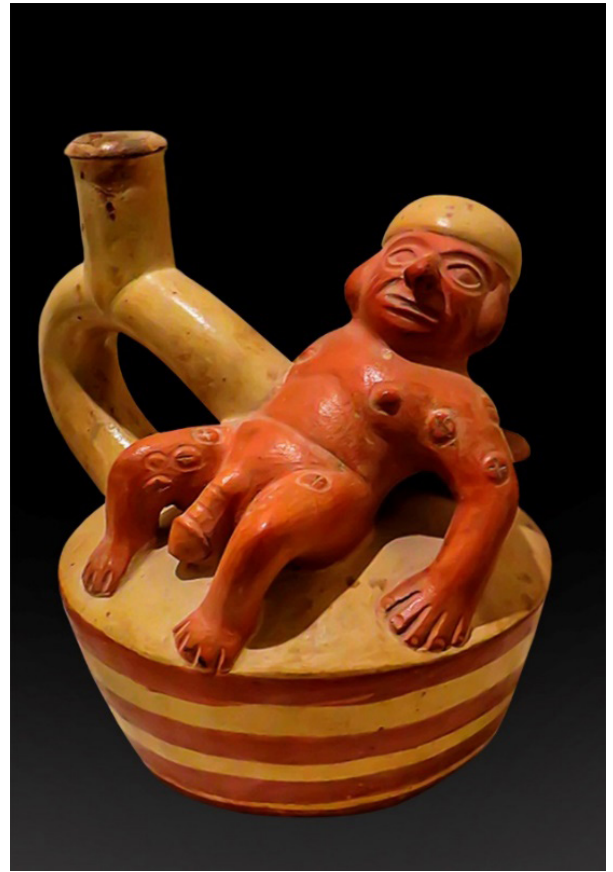

Lesiones de sífilis secundaria. Cerámica mochica. Museo de Arqueología Rafael Larco Herrera (MARLH), Lima, Perú.

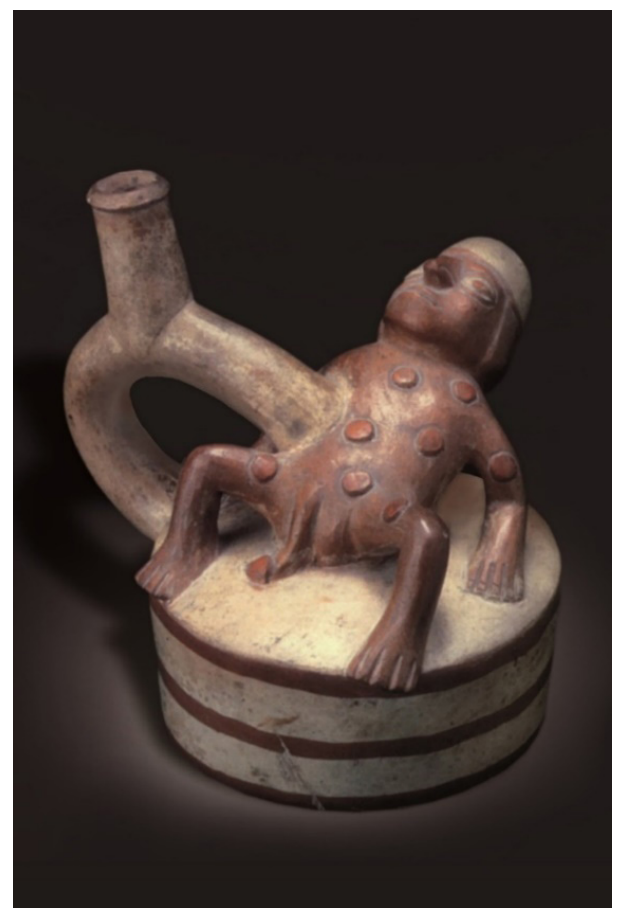

Lesiones de sífilis secundaria. Cerámica mochica. Museo Nacional de Arqueología e Historia del Perú (MNAAHP), Lima, Perú. 


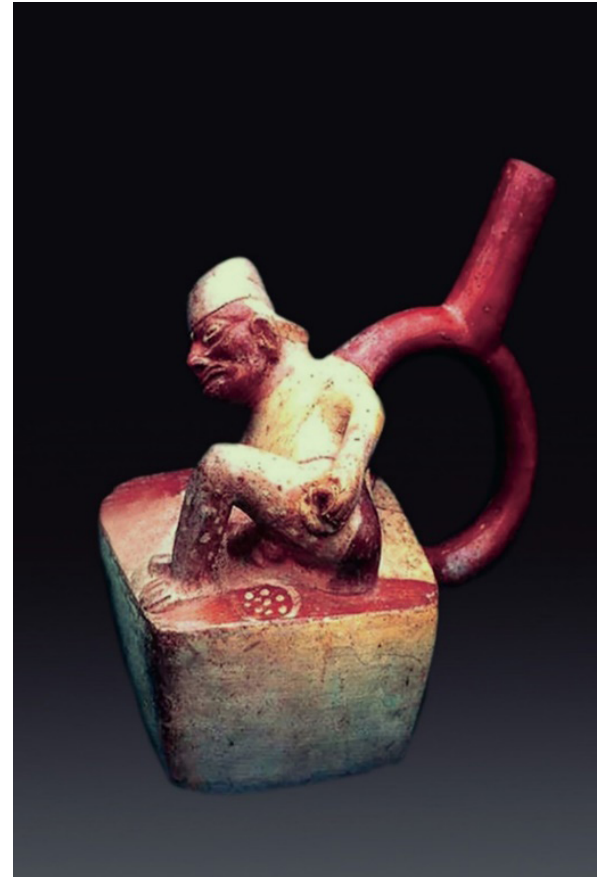

Enfermo curándose lesiones probablemente ocasionadas por sífilis. Obsérvese el recipiente con sustancias curativas. Cerámica mochica. MARLH.

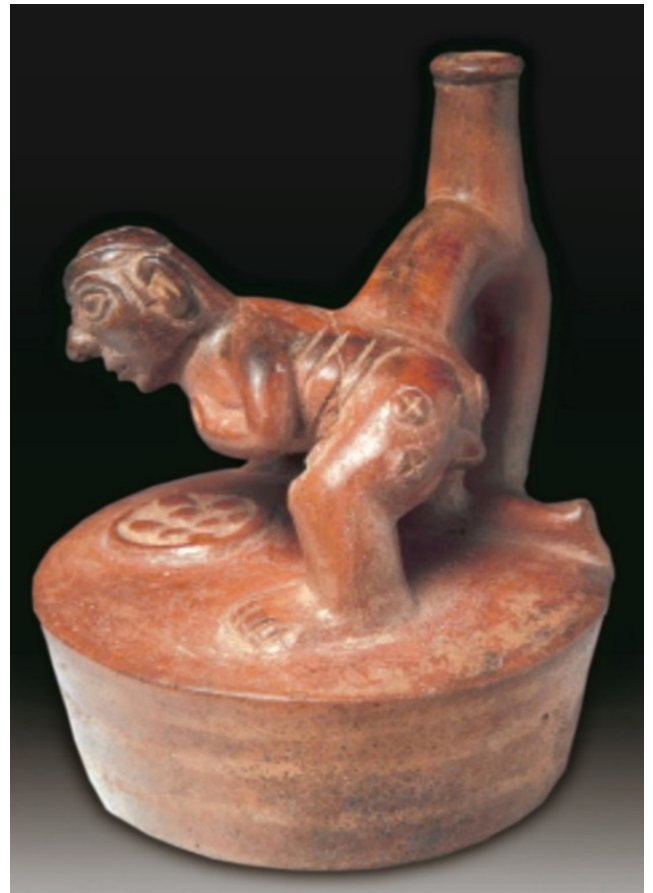

Enfermo curándose lesiones probablemente ocasionadas por sífilis. Obsérvese el recipiente con sustancias curativas. Cerámica mochica. MARLH. menciona a la infusión del polvo de la corteza del árbol de la quina, conocida con el nombre de "árbol de las calenturas", cascarilla o corteza peruana, a la infusión de una planta muy pequeña llamada chuquicanlla; y, al baño con tisanas de chilco que hacía desaparecer rápidamente la fiebre. ${ }^{4}$ Nicolás Monardes, médico y botánico español, alude a la infusión de semillas de un árbol llamado vilca y a la infusión de la raíz de zarzaparrilla, que además de tener efecto diurético y antisifilítico, se empleaba como antipirético. ${ }^{5}$ En fin, existen otras plantas con efectos antipiréticos como el cuchu cuchu, el ulux y la escobilla del Perú, etc.

En el tratamiento de la litiasis del tracto urinario empleaban medicamentos de origen vegetal o animal. Monardes habla de un medicamento que era preparado de una hierba que solo crece en las montañas del Perú llamada cachos; y, según los aborígenes, era muy eficaz para eliminar o deshacer los cálculos del riñón y de la vejiga, así anota lo siguiente: "expele las arenas y las piedras que se hacen en los riñones, y lo que es más dicen que el uso della deshaze la piedra de la vejiga". Monardes, incluso nos dice la forma cómo los aborígenes preparaban este medicamento: "molian las simientes (semillas) del Cachos y la mezclaban con alguna agua adecuada, y le daban de beber al enfermo.

Por su parte el padre Bernabé Cobo, cuenta que los aborígenes peruanos empleaban el haquismaci y el añu o isaña para tratar la litiasis del riñón. "Quiebran y disuelven la piedra de los riñones", anota el religioso; y, para este propósito, Cobo menciona a los "polvos de una piedra que sacaban de la cabeza del Manati", que probablemente es la misma que Monardes menciona como "sacada de la cabeza del Tiburón"., 4,5

La estenosis de la uretra, causada probablemente por adherencias o vegetaciones secundaria a 


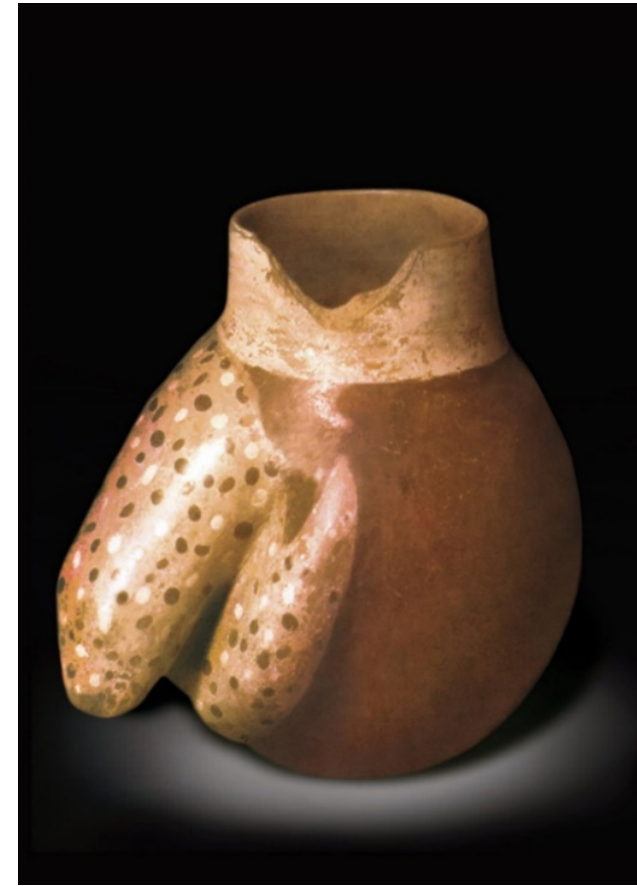

Representación de un pene con lesiones probablemente de sífilis. Cerámica Nazca. MNAAHP.

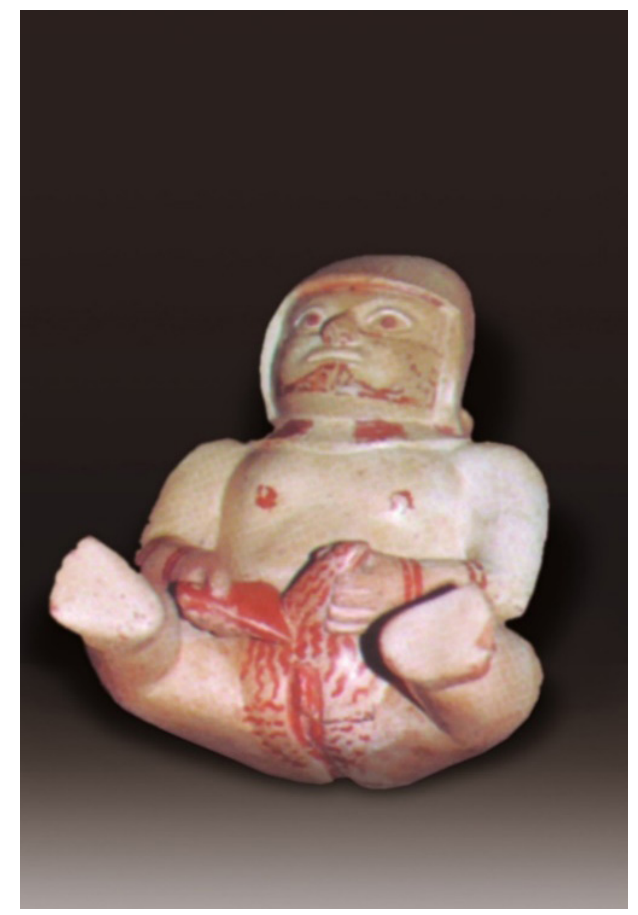

Representación de un hermafrodita, con amputación de su miembro viril. Obsérvese las mamas grandes y el sangrado perineal. Cerámica Mochica. MNAAHP. enfermedades venéreas como la gonorrea, las trataban mediante dilataciones, en la que el cirujano (sirkak) empleaba el tallo de una hierba llamada anchurapa. Este tallo es recto, duro, liso y flexible $\mathrm{y}$, a decir del padre Bernabé Cobo, al introducirlo en la uretra para realizar las dilataciones, producían poco dolor. ${ }^{4} \mathrm{Al}$ respecto, el religioso anota lo siguiente: "esta es una yerba que produce unas varillas muy lisas y derechas, su temperamento es caliente y seco; aprovechándose los indios de estas varillas, y metiéndolas por la vía de la orina cuando se sienten alguna carnosidad, porque sin mucho dolor la extirpan y la gastan".

No es de extrañarse que, para realizar las dilataciones, como en otras operaciones quirúrgicas, al paciente le daban de beber chicha preparada de maíz con ishpingo hasta embriagarse o algún preparado de chamico o de floripondio, solanáceas que se empleaba para mitigan el dolor.

En el antiguo Perú, existía gran variedad de vegetales con propiedades diuréticas las mismas que eran empleadas en las enfermedades del tracto urinario. Por ejemplo, Cobo menciona "al coro o raiz de tabaco silvestre, a la tulma, a las raíces de amancae, al itapallo y al maiz", entre otras plantas. ${ }^{4}$ Por su parte, Monardes registra a la zarzaparrilla, cola de caballo, barbas del choclo, cachos y maíz, con eficaces propiedades diuréticas. ${ }^{5}$ Otros cronistas, señalan al, canllo, orcco - canlli, llamppu - quisa, china - quisa, mangapapui, maychacha, verbena, etc. Algunos de estos vegetales aún existen y son empleados con el mismo propósito por algunos habitantes de nuestro país.

La presencia o ausencia de la sífilis entre los aborígenes del antiguo Perú ha sido objeto de considerable debate. A la luz de los hallazgos de restos óseos de antiguas civilizaciones peruanas con lesiones características de esta treponematosis, a las evidencias que muestran los espléndidos ceramios mochicas que representan varones con lesiones típicas de sífilis, y a las comunicaciones de antiguos 
cronistas, no existen dudas de que esta enfermedad estuvo presente desde antes del contacto con los conquistadores españoles. ${ }^{6-8}$

La cerámica mochica muestra piezas representando individuos con lesiones de sífilis secundaria; y, el hecho que ellos están desnudos mostrando los genitales sugiere la forma de contagio.

Los hallazgos de cráneos con lesiones sifilíticas del periodo incaico preconizado por Julio C. Tello confirman la existencia de la sífilis en el antiguo Perú. 6 En otros entierros precolombinos estudiados por Weiss y Verano también identificaron lesiones de sífilis en los cráneos. ${ }^{7,8}$

Son muchos los cronistas que se refieren a la sífilis como una enfermedad venérea que existió entre los indígenas peruanos, y a ésta le llaman bubas. La sífilis no solamente afectaba a la gente de clase social baja sino también la clase alta del imperio incaico. En efecto, Flores refiere que el médico osteólogo George Eaton, miembro de la expedición de Hiram Bingham a Machu Picchu, en 1911, descubrió la tumba de una sacerdotisa o mamacona, superiora del convento de las acllas o mujeres escogidas vírgenes de singular belleza que estaban al servicio del Inca o del dios Sol), y al realizarle un estudio osteopatológico encontró que la sacerdotisa sufría de sífilis. ${ }^{9}$

Los cronistas José de Acosta ${ }^{3}$, Bernabé Cobo ${ }^{4}$, Pedro Cieza de León ${ }^{10}$ y Antonio de Herrera y Tordesillas ${ }^{11}$ refieren a la zarzaparrilla y al guayacán, llamado también palo santo, como medicamentos eficaces usados en la curación de las bubas.

Cieza de León, de la zarzaparrilla manifiesta lo siguiente: "muchos que traían las asaduras dañadas y los cuerpos podridos, con sólo beber el agua de estas raices quedaban sanos; y otros que venían agravados de las bubas y las traían metidas en el cuerpo, bebiendo de esta agua los dias convenientes también sanaban. En fin, muchos

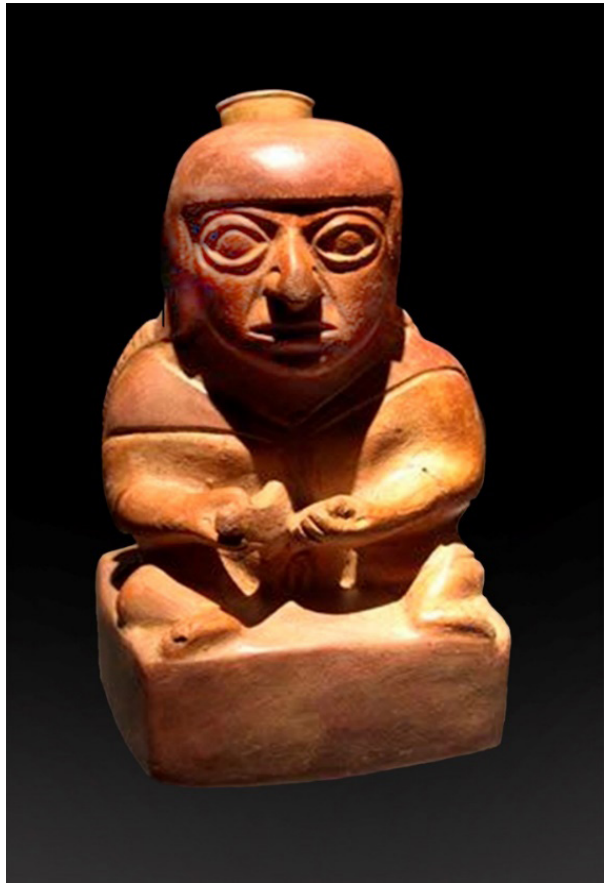

Representación de un hermafrodita intentando amputarse el miembro viril, y en la parte inferior se observa la vulva. Cerámica Mochica. MNAAHP.

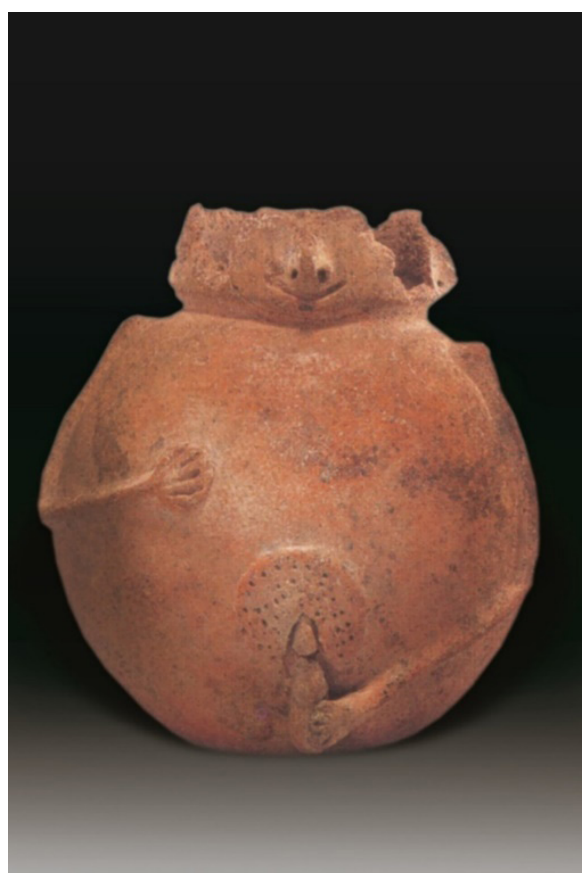

Ceramio que representa un hermafrodita que con la mano izquierda lateraliza el pene para hacer notar la vulva. Cerámica Virú o Gallinazo. MNAAHP. 
fueron hinchados y otros llagados y volvieron a sus casas sanos". ${ }^{10}$

El padre Bernabé Cobo señala que el coro o raíz del tabaco silvestre (Nicotina paniculate) y el cocimiento del pinco pinco, son remedios muy eficaces para aliviar los dolores causados por las bubas $^{4}$.

La presencia de hermafroditas entre los aborígenes del antiguo Perú nos la provee el cronista indígena peruano Juan de Santa Cruz Pachacuti ${ }^{12}$, y la cerámica de las culturas Mochica y Virú o Gallinazo. También existe una leyenda del padre Francisco de Dávila que menciona el tema.

Sobre el hermafroditismo es oportuno precisar o advertir algunas situaciones clínicas de esta malformación El hermafroditismo es una malformación congénita que se caracteriza por la coexistencia de órganos sexuales femeninos y masculinos en un mismo individuo; $\mathrm{y}$, es originado por un trastorno del desarrollo sexual. Esta malformación es de presentación excepcional.

Aun cuando una persona hermafrodita pueda poseer ovarios y testículos, no es capaz de reproducir óvulos y espermatozoides a la vez pues alguno de los sistemas sexuales se desarrolla de manera deficiente. Por esta razón, hoy en día los especialistas han cambiado el uso del término hermafroditismo por intersexualidad, ya que en realidad la persona afectada no posee en sí los genitales de ambos sexos sino apenas rasgos con un desarrollo desigual, lo que implica que uno de estos no cumple con su función.

El seudohermafroditismo es la afectación de la morfología de los genitales externos que sugiere un sexo opuesto al determinado por el mapa cromosómico. Puede ser seudohermafroditismo femenino, que se caracteriza porque los caracteres sexuales externos aparecen como masculinos pero la persona posee ovarios; $\mathrm{y}$, seudohermafroditismo

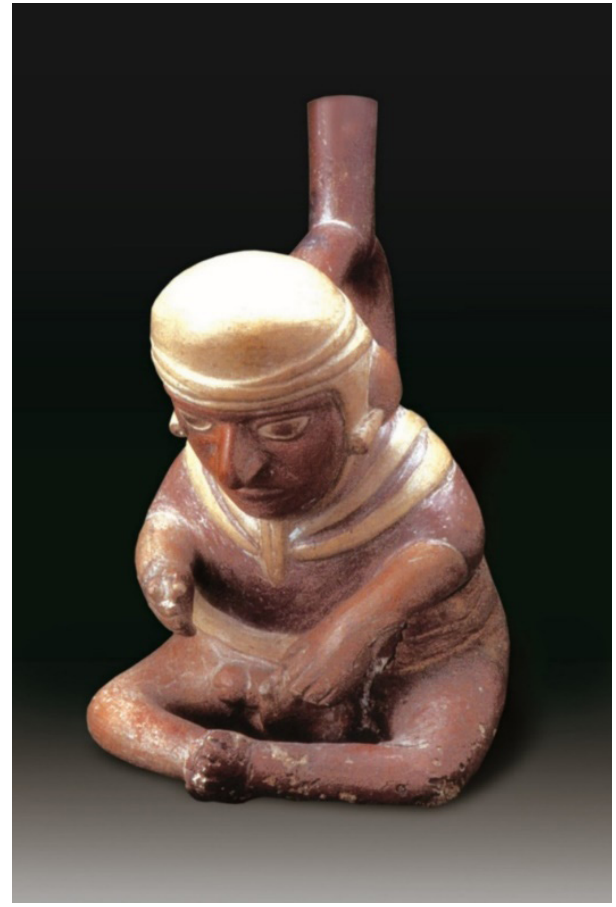

Varón que se ha extirpado una tumoración del testículo o del escroto. Con una mano sostiene el tumor y con la otra hace hemostasia en la herida. Cerámica Mochica. MARLH.

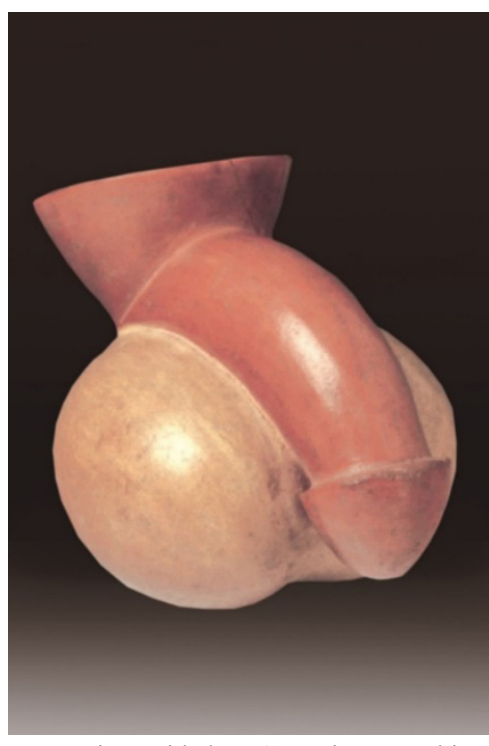

Pene circuncidado. Cerámica Mochica. MNAAHP.

masculino, cuando los caracteres sexuales externos parecen femeninos pero la persona tiene testículos no descendidos. 
La palabra hermafroditismo proviene del término hermafrodita, el cual a su vez es proviene del nombre del dios griego Hermafrodito, hijo de Afrodita y Hermes. Afrodita, al sentirse culpable de adulterio, se separó de su hijo y lo dejó en el monte de Ida (Frigia) al cuidado de las ninfas del monte, por quienes fue criado. Hermafrodito se convirtió en un joven muy hermoso y atractivo. Un buen día fue a bañarse en el lago de la náyade o ninfa Salmacis. Ésta, al verlo desnudo y seducida por su belleza, quiso poseerlo y consumar su deseo pero Hermafrodito hizo resistencia. Entonces, Salmacis rogó a los dioses del Olimpo que unieran sus cuerpos para siempre, de modo que fueran uno solo. Los dioses accedieron y, desde entonces, Hermafrodito adquirió un cuerpo de doble sexo y perdió su virilidad. Hermafrodito, pidió también a los dioses que todos aquellos hombres que se bañaran en aquel lago sufrieran la misma transformación que él, deseo que le fue concedido.

El doctor Fernando Cabieses refiere que, como en otras religiones primitivas, el dios hermafrodita también estaba simbolizado en el antiguo Perú en diversas mitologías. ${ }^{13}$ Describe que existen pequeños ídolos de bronce que muestran ambos sexos encontrados en tumbas incaicas y una antigua leyenda de la sierra central, obtenida por el padre Francisco de Dávila en el siglo XVI, que habla de Champi Ñampi, la mujer del mago-médico Wathaycuri que siempre daban a luz hermafroditas. ${ }^{13}$

El cronista Juan de la Cruz Pachacuti, en su libro Relación de Antigüedades de este Reino del Perú nos cuenta que, en el cumpleaños del príncipe Amaru Túpac Inca, hijo de Pachacutec Inca Yupanqui y nieto del Viracocha Inca Yupanqui, los curacas y mitimaes de Carabaya traen como regalo un animal de plumaje de varios colores llamado chuqui chinchay que era el guardián sagrado de los hermafroditas. ${ }^{12}$

Pachacuti narra el acontecimiento de la siguiente manera: "Pachacuti Inca Yupanqui parte para su ciudad del Cuzco, en donde halló que su padre Huiracochampa Inca Yupanqui estaba ya muy viejo y enfermo. Llegado, hace la fiesta de su llegada y tras de esto hace la fiesta de Cápac Raimi con gran alegría. Al viejo le presenta a su hijo, su nieto y después hace la fiesta del nacimiento del infante: se llamó Amaro Topa Inca. Entonces los curacas y mitimaes de Carabaya traen a Chuqui Chinchay animal muy pintado de todos los colores (dicen que era Apo de los otorongos), cuya guarda da a los hermafroditas, indios de dos naturas. Este mismo Inca ha mandado a recoger a todos los enanos y corcovados, los cuales, dicen siempre se ocupaban en hacer vestidos para el infante. Asimismo, dicen que para este Inca trajeron piedras que alumbraban de noche, sacándolas de un escollo de Apurímac". ${ }^{2}$

Por otra parte, en la cerámica de las civilizaciones pre incas, se han identificado tres preciosas piezas que representan con un alto nivel de realismo a individuos hermafroditas. Desconocemos la existencia de otros ceramios que representen esta malformación congénita. El primer ceramio, personifica a un hermafrodita que se encuentra en posición semi sentado. Se observa nítidamente que el individuo con una de sus manos coge su pene, y con la otra empuña un cuchillo o tumi e inicia la amputación del miembro viril; por debajo del pene se encuentra la vulva y todo el periné está manchado de sangre. Obsérvese que las mamas del individuo son grandes. El segundo, representa a un hermafrodita que se encuentra en posición sentado, y también se observa nítidamente que el individuo coge su pene con una de sus manos y con la otra empuña un cuchillo o tumi dispuesto a amputarse el miembro viril; por debajo de éste se observa la vulva. Ambos ceramios se encuentran en el Museo Arqueológico Rafael Larco Herrera (MARLH) en Lima y pertenecen a la cultura Mochica. El ultimo simboliza a un hermafrodita que se encuentra en posición sentado, y se observa que el individuo coge su pene con una de sus manos para dejar visible la vulva. Este ceramio pertenece a la cultura Virú o Gallinazo y se halla en MNAAHP. 
La única evidencia que se tiene de las tumoraciones de los genitales externos en los aborígenes peruanos proviene de la cerámica mochica, del MARLH, en la que las hábiles manos de los alfareros han plasmado en un ceramio individuo extirpándose una tumoración del escroto. El ceramio en mención representa a un varón que se encuentra en posición sentado y que se ha extirpado una tumoración probablemente del escroto, con una mano sostiene el tumor y con la otra hace hemostasia en la herida. Este ceramio también ha sido estudiado por otros autores, algunos de los cuales sostienen que probablemente el individuo se ha extirpado el testículo por presentar un tumor.

Del análisis de los ceramios que representan el miembro viril de los varones del antiguo Perú se puede alegar que la fimosis era tratada, como en la actualidad, mediante la circuncisión, llamada también postectomía. El doctor Juan Lastres sostiene que la operación se realizaba por motivos religiosos. ${ }^{14} \mathrm{El}$ doctor Fernando Cabieses refiere que la circuncisión fue una práctica común en las culturas Mochica y Virú. ${ }^{13}$ Por su parte, Rafael Larco Hoyle manifiesta que efectivamente los mochicas realizaban la circuncisión pero no asevera si era realizada con frecuencia o si los motivos que condujeron a los cirujanos a realizarla fue por razones de higiene o por terapéutica. ${ }^{15}$ Cualquiera que haya sido el motivo, ritual o terapéutico, lo cierto es que en el antiguo Perú se realizaba la circuncisión; y, a juzgar por lo se evidencia en los ceramios, la técnica quirúrgica fue buena. Por lo tanto, se rechaza lo que dice el padre Acosta, quien refiere que los antiguos peruanos no se circuncidaban. ${ }^{3}$ Probablemente, este cronista se refería sólo a la cultura Inca, ya que no existe información al respecto de ellos.

\section{Referencias biliográficas}

1. Calancha, Fray Antonio de la. Crónica Moralizadora de la Orden San Agustín en el Perú (1653). Tomo II, Lima, 1976.

2. Garcilaso de la Vega, (Inca). Comentarios Reales de los Incas. Lima (1603). Editorial Fondo de Cultura Económica, 1991.

3. Acosta, José de. Historia Natural y Moral de las Indias (1590). Madrid: Consejo Superior de Investigaciones Científicas, 2008.

4. Cobo, padre Bernabé. Historia del Nuevo Mundo (1653). Madrid, Atlas, 1956.

5. Monardes, Nicolás. La Historia Medicinal de las Cosas de Nuestras Indias Orientales. Sevilla, 1574.

6. Tello, Julio César. La antigüedad de la sífilis en el Perú. Lima, Imprenta San Martín, 1909.

7. Weiss, Pedro. Origen americano de las treponemiasis. sífilis, mal del pinto. Revista de Ginecología y Obstetricia. 1956;2 (1):41-68.

8. Verano JW y Lombardi GP. Paleopatología en Sudamérica Andina. Bull Inst fr Études andines. 199;28 (1): 91-121.

9. Flores Cevallos E, Flores Cevallos L y Burstein Z. Historia de la dermatología en el Perú. En: Galimbert, R. Pierini, AM. y Cervini, AB. Historia de la Dermatología Latinoaméricana. Toulouse-Francia: Éditions Privat, Fondo Educativo de Laboratorios Pierre Fabre Dermo-Cosmétique, 2007.

10. Cieza de León, Pedro. El Señorío de los Incas (1533). Madrid, Dastin S.L., 2000

11. Herrera y Tordesillas, Antonio de. Historia general de los hechos de los castellanos en las Islas y Tierra Firme del Mar Océano. Madrid, 1615.

12. Pachacuti, Juan de Santa Cruz. Relación de las Antigüedades de este Reino del Perú (1620 o 1630). Lima: Fondo de Cultura Económica, 1995.

13. Cabieses Molina, Fernando. La salud y los Dioses: La Medicina en el Antiguo Perú. Lima: Fondo Editorial de la Universidad Científica del Sur, 2007.

14. Lastres, Juan B. La Historia de la Medicina: La Medicina Incaica. Tomo I, Edit. U.N.M.S.M. Lima: Imprenta Santa María, 1951.

15. Larco Hoyle, Rafael. Los mochicas. Tomo II. Museo Arqueológico Rafael Larco Herrera, Lima, 2001.

\section{Correspondencia:}

Emiliano Paico-Vílchez

epaicov@gmail.com

Fecha de recepción: 15-02-2021.

Fecha de aceptación: 15-06-2021.

Conflicto de interés: ninguno, según los autores.

Financiamiento: por los autores. 